\title{
The impact of social advertising on mental health of population
}

\author{
Oleksandra-Mariia Dzhovadian
}

Lviv Polytechnic National University, Lviv, Ukraine

\section{Extended Abstract Keywords}

Social advertising, mental health, social campaigns, stress resistance.

Address for correspondence:

Oleksandra-Mariia Dzhavadian,Ph.D student, Department of Sociology and Social Work, Lviv Polytechnic National University, Lviv, Ukraine. e-mail: alexandradzdz@gmail.com

This work is licensed under a Creative Commons Attribution-

NonCommercial 4.0 International License (CC BY-NC 4.0).

\section{(c) (1) (8)}

(C) Copyright: Dzhavadian, 2020

Licensee NDSAN (MFC- Coordinator of the NDSAN), Italy

DOI: http://doi.org/10.32437/mhgci.v4i2.95

\section{Introduction}

In Ukraine, the first place among mental disorders (over 40\%) - those that arise as a result of drug and alcohol addiction. In 2nd place disorders due to organic impressions of the brain, 3 - disorders of intellectual development, 4 schizophrenic disorders. 5 - neurotic, anxiety disorders, including depression. Although according to the WHO, Ukraine ranks in the world one of the first places in the incidence of depression. At the end of 2016, 261240 patients with mental disorders in Ukraine had a disability group (Order of the Cabinet of Ministers of Ukraine, 2017).

\section{Purpose}

The purpose of the paper is to analyze the relationship between mental health of population and social advertising. And to show the importance of the impact of social advertising on health (not only physical but also and mental). To explore global social advertising campaigns on mental health of population.

\section{Results and Discussion}

The World Health Organization (WHO) gives the following definition of health: "Health is a state
Submitted for publication: 20

August 2020

Received: 20 August 2020 Accepted for publication: 26

October 2020 of complete physical, mental and social wellbeing." It includes three components: the absence of disease; the work of the organism is coordinated and allows to fully perform all functions; a state of harmony within oneself and with each other in the physical and social environment. Accordingly, mental health is an important part of it.

If these three indicators are normal, then a person becomes stress-resistant, able to work, productive and active in public life. It also depends on the emotional state whether a person is able to perform certain social roles, to realize and manage their own emotions, to be open to development and learning (World Health Organization, 2020).

The level of quality of life, labor productivity, active social position, unity, social peace and stability depend on the state of mental health, which has a positive effect on the economic and social development of the country.

The World Health Organization website has a report on the 2013 meeting: "The World Health Organization has approved a Comprehensive Plan of Action in the field of mental health for the period 2013-2020 and extended until 2030. The plan aims to implement global and national actions to strengthen mental well-being, prevent mental disorders, and provide medical care. This 
plan is aimed at achieving 4 objectives, one of which includes at the primary level comprehensive integrated health and social care, which responds quickly to change (World Health Organization, 2013).

One of the types of primary prevention in social work is social advertising. After all, quite a few people seek help in the right institutions. This may be due to shame, non-recognition of the problem or problem situation, ignorance of one's rights, or information about the possibility of receiving assistance that can be provided by the state or a specialized organization.

It is through social advertising that you can influence the mental health of society, informing about activities, organizations, laws, programs, services and much more that will help people strengthen themselves or help loved ones. As a result, more people will be informed and at least a percentage of situations will be avoided, because people in difficult emotional states are more exposed.

In Ukraine, the development of social advertising is not very high, because many organizations do not pay attention to non-profit campaigns, and the state, due to many factors, cannot afford the significant cost of social advertising.

Most developed countries have their own programs and projects to combat various diseases, such as "She Entrepreneurs", "Ispire2Entreprise", "Educate!". These are programs to combat cancer, diabetes, HIV/AIDS, vaccination support, campaigns for the right treatment of people with disabilities, members of national, racial, ethnic, religious and linguistic minorities. For example, campaigns against risky behavior cover the three most relevant topics: smoking, drug use and excessive or illegal alcohol use (Platforma, 2015).

\section{Conclusion}

Thus, timely detection and resolution of problems will not worsen human health and prevent its violation. It is the right social advertising on mental health that can correct this. If enough people, especially those at risk, are informed, many negative consequences can be avoided. It is possible that the state of our country's economy does not allow sufficient funding for the social sphere, but the inspiration of our people creates special opportunities and a strong basis for the future. World practice sets a good example to follow and helps our country to develop social initiatives, in particular in social advertising as one of the tools of prevention in the social sphere.

\section{Conflict of interest}

The author declares that she has no conflict of interests

\section{References}

World Health Organization (30.03.2020). Mental health. URL: https://www.who.int/ru/newsroom/fact-sheets/detail/mental-healthstrengthening-our-response

Order of the Cabinet of Ministers of Ukraine (27.12.17). "On approval of the Concept of mental health development in Ukraine for the period up to 2030" № 1018-r URL: https://zakon.rada.gov.ua/laws/show/10182017-\% D1\% 80\#Text

World Health Organization (2013). Comprehensive mental health action plan 2013-2020-2030. URL: https://www.who.int/mental health/action plan 2013/en/

Platforma (25.03.2015). Five social projects for leaders and entrepreneurs. Retrieved from URL https://platfor. ma/magazine/textsq/social/social-projects-entrepreneurship/ 